\title{
TAX EVASION, LEVEL OF INTERNET CORPORATE REPORTING AND FIRM VALUE: EVIDENCE FROM INDONESIAN MANUFACTURING FIRMS
}

\author{
Asmoro Priandhita Sukowidyanti \\ Taxation Program, Faculty of Administrative Science, Universitas Brawijaya, Indonesia \\ E-mail: priandhita.asmoro@gmail.com
}

\begin{abstract}
As a developing country that accumulates its source of revenue to taxes, Indonesia is not spared from tax compliance issues. The low level of tax compliance indicates a different point of view between the government and the Taxpayer. The low level of tax compliance indicates a different point of view between the government and the Taxpayer. Taxpayers still consider the obligation to pay taxes as an expense that can reduce their income or profits. Therefore, the rational Taxpayer will try to minimize the tax burden. One of them is by doing Tax Evasion. Taxation management is more often done by the Taxpayer Agency, especially the Manufacturing company. This is because the company has a very high business risk. Tax Evasion can increase organizational complexity which in turn can reduce financial transparency. Therefore, companies are required to disclose more information and provide flexible reporting systems that facilitate stakeholders. This encourages companies in the world to take advantage of the development of information technology and interconnection networking through internet corporate reporting. Utilization of internet corporate reporting is expected to increase the value of the company. This study aims to analyze the relationship between the concept of Tax Evasion, the level of internet corporate reporting disclosure, and the firm value. The results showed that the three hypotheses in this study were accepted. Tax Evasion affects the level of internet corporate reporting disclosure. In addition, Tax Evasion also directly or indirectly influence the firm value through the level disclosure of internet corporate reporting.
\end{abstract}

\section{KEY WORDS}

Tax evasion, internet corporate reporting, firm value, taxes.

Tax compliance is a classic problem that faced by tax authorities around the world. Tax compliance refers to the individual's willingness to act according to the laws of taxation and tax administration without law enforcement (James and Alley, 2002). Andreoni, et al. (1998) defines tax compliance as taxpayer awareness to comply with a country's tax regulations. In other words, tax compliance is the implementation of tax obligations which include calculation, payment and tax reporting accurately and on time in accordance with applicable tax law (Roth, et al, 1989).

Tax compliance levels between countries are different. Tax compliance in developed countries like the United States in general is already high. Meanwhile, tax compliance in developing countries such as Indonesia is still relatively low. Directorate General of Taxes data's in 2016 indicates that taxpayer compliance shapes a pattern of a reversed pyramid. The population of individuals and entities reached 249 million and 27.25 million respectively, but registered individual taxpayers only 27.63 million and corporate taxpayers 2.48 million. Meanwhile, the number of tax returns (SPT) reported for individual taxpayers is 10.25 million and corporate taxpayers 0.22 million (pajak.go.id, 2017). In addition, the achievement of tax revenue target is never reached $100 \%$, in 2014 the tax revenue only reached $85.90 \%$, while in 2015 only reached $81.97 \%$ (pajak.go.id, 2017).

The low level of tax compliance indicates a different point of view between the government and the Taxpayer. From the macro utopia perspective or the government's point of view, taxation is a citizen's obligation to fund governmental tasks and be the backbone of state revenue for development. On the other hand, based on financial micro perspective or taxpayer's point of view, a tax is considered as a transfer of economic resources from the 
private sector to the public sector which results in reduced purchasing power of the taxpayers (Santoso and Rahayu, 2017). Taxpayers still consider the obligation to pay taxes as an expense that can reduce their income or profits. Therefore, a rational Taxpayer will try to minimize his tax burden by doing tax management.

Tax management is more often done by corporate taxpayers. Tax management is a sequence of efforts to implement management functions that include planning, organizing, implementing and controlling for the implementation of taxation rights and obligations to run effectively and efficiently (Pohan, 2013). Tax Planning is an early stage in the implementation of tax management functions in the form of systematic analysis of business strategy and various tax treatment options to generate maximum profit after tax (Scholes et al., 2009). Scholes et al (2009) drafted the tax planning concept based on the dimensions of legality and compliance level. Legality dimension ranges from perfectly legal, gray area, to illegal with the intention of doing fraud. Meanwhile, the dimensions of compliance range from strict compliance, noncompliance with the unfavorable tax system, and noncompliance. Therefore, there are three ways that the Taxpayer can do to reduce the amount of tax burden, namely Tax Avoidance, Tax Evasion, and Tax Saving.

Balakrishnan et al (2010) state that Tax Evasion can increase organizational complexity which in turn can reduce financial transparency. The demand for companies to disclose more information and provide flexible reporting systems to facilitate stakeholders accessing information has encouraged companies in the world to utilize the development of information technology and interconnection networking (Wilis, 2004). The use of the Internet in the corporate information reporting process has an impact on the change of models and channels that companies use to interact or communicate with stakeholders (FASB, 2001). Company information that has been presented in printed form (paper-based corporate reporting) has shifted into web-based corporate reporting information (web-based corporate reporting) that uses digital data as a resource. The process of corporate information communication, both financial information and nonfinancial information related to resource and corporate performance by utilizing web-based applications known as internet corporate reporting (ICR) (Dutta dan Bose, 2007).

Alvarez et al. (2008) state that the motivation of management to disclose information through the website can be explained by Agency Theory. Alvarez et al. (2008) also mention that two other supporting theories, Signaling Theory and Political Cost Theory can be used to explain the practice of ICR conducted by the company. The company objective performing ICR according to agency theory is to reduce the asymmetry of information that occurs between managers and shareholders. In addition, the ICR is expected to control the actions of managers who tend to prioritize their interests rather than owners interests. ICR according to Signaling Theory aims to provide a signal to the capital market in order to reduce the occurrence of information asymmetry, optimize financing costs, and increase firm value. According to the Political Cost Theory, the company conducts ICR to avoid the transfer of corporate wealth to public sector and/or political sector. A voluntary disclosure will encourage good relationships between a company, government and public sector as shown by reduced political costs, such as taxes and certain profits by companies such as subsidies and government actions that support the company.

The practice of ICR has grown rapidly in various countries. The results of Lymer's et al. (1999) research with a sample of 660 companies from 22 countries included into the 30 largest companies on the Dow Jones Global Index show that only $14 \%$ of companies that do not have websites and $25 \%$ have websites but are not used to report financial information. It shows that companies have considered the Internet as an important medium for disseminating company information to stakeholders (Lakhal dan Boubaker, 2005). However, the level of ICR disclosure still varies between companies in various countries, including in Indonesia. The Almilia (2009) study shows that 213 companies or $62 \%$ of the 343 public companies listed on the Indonesia Stock Exchange (IDX) in 2008 have conducted ICR practices with varying disclosure quality. $70 \%$ of the 213 companies disclose the complete financial statements and the rest do not disclose complete financial statements. The differences in the level of the disclosure are due to the fact that the ICR is still voluntary and 
unregulated by regulators (Craven and Marston, 1999; Oyelere et al., 2003; Marston and Polei, 2004; Khan, 2007; Khlifi and Bouri, 2009).

The variation in the level of ICR disclosure due to the unavailability of such standards has prompted research to provide empirical evidence of the factors influencing management decisions to disclose or not to disclose information on the company's website. Tax Evasion is suspected to be one of the factors driving the company to disclose information through the website more broadly. Companies that implement ICR provide more open information that allows the market to evaluate the future prospects of the company more efficiently (Alvarez et al., 2008). Nevertheless, Hope et al. (2013) research show different results, companies that do Tax Evasion tend to disclose fewer financial information to hide their cheats.

The use of ICR by firms can encourage the market to provide a high price for the company's stock if the company is considered to offer a good future prospect (Alvarez et al., 2008). Hunter and Smith (2007) research prove that the market responds more positively to companies that implement ICR than companies that do not implement ICR. The response is a rise in stock prices for companies that implementing the ICR. That's because investors consider companies that implement ICR provide better protection to investors over the uncertainty of company's condition. The result of this research is supported by Lai et al. (2009) research which proves that companies that utilize ICR have higher abnormal return rate than companies that do not implement ICR. The high stock price indicates the high value given by shareholders and other stakeholders to the company. Silva dan Alves (2004) research on publicly traded companies in Latin America shows that the level of ICR disclosure affects the firm's value calculated using Tobin $Q$ ratio.

Although some researchers have been able to prove that information disclosure through the company's website can increase the value of the company, but some researchers claim that the absence of standards governing the practice of the ICR has the potential to provide information completeness, information comparability, and information reliability (Ashbaugh et al, 1999). The absence of standards also has the potential to create doubts regarding the authenticity and credibility of the information disclosed through the company's website. In addition, the absence of an online information disclosure standard triggers information security issues. Thus, there is still doubt that the ICR is able to provide assurance to investors on the truth and accuracy of information especially that can detect the actions of Tax Evasion conducted by the company. Thus, ICR is considered not able to provide added value for companies that implement it.

\section{THEORY AND HYPOTHESES}

Tax evasion refers to the incorrect acts committed by the taxpayer regarding the liability in paying taxes (Suminarsasi \& Supriyadi, 2011). Mardiasmo (2009) interpret Tax Evasion as an attempt made by the taxpayer to lighten the tax burden by violating the law. The taxpayers ignore the formal provisions of taxation that become obligatory, falsifying documents, or filling data incompletely and incorrectly. There is a difference between Tax Avoidance and Tax Evasion. Tax Avoidance does not violate legislation and only exploits the weakness gap in the law. While Tax Evasion is an effort undertaken by the company to avoid taxation obligations by violating existing legislation.

The reason there are still many taxpayers perform such actions because the incentives of Tax Evasion exceeds the sanctions or fines to be paid even though the tax law already provides the threat of criminal penalties for taxpayers. According to Suandy (2011) there are several factors that motivate taxpayers to make tax savings with the illegal:

- Amount of tax to be paid. The greater the amount of taxes to be paid, the greater the tendency of taxpayers to commit tax violations;

- The cost to bribe the tax authorities. The smaller the cost to bribe the taxpayer, the greater the tendency of taxpayers to commit offenses;

- Possibility to get caught. The less likely a violation is detected, the greater the inclination of the taxpayer to commit a tax violation; 
- Large sanctions. The lighter the sanctions imposed on violations, the greater the taxpayer's tendency to commit tax violations.

Tax Evasion actions are also motivated by the company's efforts to minimize the transfer of resources from the company to the public sector. Resource transfers result in reduced productivity or the ability of firms to generate profits. This can be explained by Agency Theory. Jensen and Meckling (1976) stated that the agency relationship has the potential to create a conflict of interest between agent and principal. The agency relationship arises when one or more principals hire agents to provide services and decision making on behalf of the principal. Conflicts of interest arise because of the different goals of each party based on the position and importance of the company (Alvarez et al.,2008). Managers (agents) appointed by shareholders (principal) are expected to maximize the value of the company so that shareholder wealth can be achieved. However, the agent in running the company's operating activities often acts not in the interests of the principal, but acts to improve his own welfare, among others, in terms of obtaining investment, loans, or compensation contracts. Therefore, the principal will make efforts to achieve the goal, one of them by doing Tax Evasion.

Separation of ownership and control of the company has the potential to generate information asymmetry because agents have more information about the company than the principal. Companies must bear three types of agency costs due to conflict of interest and information asymmetry, i.e. Monitoring Cost, Bonding Cost, and Residual Loss Cost (Jensen dan Meckling,1976). Therefore, the company will disclose more information than mandatory disclosure to reduce the agency cost (Adina and Ion, 2008). Thus companies will tend to disclose more information when they decide to conduct Tax Evasion. The company not only carries out mandatory disclosure, but also voluntary disclosure. One form of voluntary disclosure is Internet Corporate Reporting (ICR).

Lymer et al. (1999) define the ICR as a reporting process to the public regarding the company's operating activities and financial information by business firms through company websites or communications via internet-based media. Other definitions of ICR are given by Dutta and Bose (2007), namely the process of communicating information, both financial information and nonfinancial information related to resource and company performance by utilizing web-based applications. Meanwhile, according to Marston and Polei (2004), a company is considered to practice ICR if it has distributed financial information and company performance information through the company website. Oyelere et al. (2003) provides a narrower definition of the ICR, the company has done the ICR practice if it provides a set of financial statements or financial highlights on their company's website.

ICR is still voluntary and unregulated (Craven dan Marston, 1999; Oyelere et al., 2003, Marston dan Polei, 2004, Khan, 2007; Khlifi dan Bouri, 2009). Therefore, ICR disclosure is still an incremental disclosure or complementary form of the conventional reporting process (paper-based corporate reporting) (Ashbaugh et al., 1999; Debrency dan Gray, 1999; Celik et al., 2006; Trabelsi et al.,2008). Thus, the level of ICR disclosure between companies is still varied. In general, the level of ICR disclosure can be assessed through two things, namely the information content and the presentation format (FASB, 2000; Aly et al., 2009; Bhuiyan et al., 2008). Information disclosed through the company's website there are two types, namely financial information and nonfinancial information. Based on this, the first hypothesis in this study are:

$\mathrm{H}_{1}$ : Tax Evasion affects the level of Internet Corporate Reporting disclosure.

Tax evasion is considered a violation of religion or unethical when taxpayers do not pay according to the amount they owe (Hutami, 2012). Tax Evasion by some parties is considered as a signal of a problem in the company's finances. Stakeholder has a tendency to respond negatively to tax evasion action by the company. The negative response demonstrates the declining level of stakeholder confidence in corporate management. The decline in stakeholder trust is reflected in the low value of the company. This is contrary to the company's ultimate goal by the theory of the firm that maximizes the value of the firm by increasing the prosperity of the owner or shareholders (Brigham, 1996 in Wahidahwati, 2002). Maximizing the value of a company is very important for a company because by 
maximizing the value of the company means the company will increase the wealth of the owner (shareholder) (Brigham, 1996 in Wahidahwati, 2002). The value of the firm is the investor's perception of the company's success rate as reflected by the stock price (Fama, 1978). If the stock price rises then the value of the company will increase. The increase in the value of the company will be followed by an increase in shareholder wealth because shareholders will gain a high rate of return on rising stock prices. Meanwhile, Husnan (2000: 7) defines the value of the firm as the price that would be paid by the prospective buyer if the company is sold. Thus, the act of Tax Evasion if done not carefully can harm the company that is the decline in the value of the company in the eyes of shareholders. Based on this, the second hypothesis in this study are:

$\mathrm{H}_{2}$ : Tax Evasion affect the value of the company.

For companies that issue shares in the capital market, the traded stock price becomes an indicator of firm value. The stock price is the fair price that can be used as the company's value proxy (Christiawan and Tarigan, 2007). That is because the stock price in the capital market is formed based on an agreement between the demand and supply of shares determined by the market participants in accordance with the information in circulation. Fama (1978) state that the value of firms formed through indicators of the market value of shares is largely determined by investment decisions. Meanwhile, the quality of investor investment decisions is strongly influenced by the quality of corporate information disclosure (Singhvi and Desai, 1971).

From the explanation it can be seen that the quality of corporate information disclosure plays an important role in increasing the value of the company. Singhvi and Desai (1971) mentioned that the high level of corporate transparency indicated by the amount of information available in the market and the ease of accessing information can have an impact on the formation of a company's reputation that indirectly increases the company's value. The effect of the level of disclosure of information on the value of this company can be explained by using Signaling Theory.

Signaling Theory was developed on the basis of the information asymmetry between well informed managers and poorly informed shareholders. Information asymmetry occurs because management does not fully convey information to outsiders. Information asymmetry can affect firm value to the capital market. Therefore, the company will provide a signal to outside parties in the form of comprehensive information including financial information and nonfinancial information to reduce information asymmetry. The availability of information will help the investor to provide a better assessment of the company as indicated by the high value of the company's stock. Signals are actions taken by the company's management to provide guidance to investors about how management views the prospects of the company (Brigham and Houston, 2001 in Mulianti, 2010). A good signal is a signal that can not be imitated by another company that has a lower value. According to Signaling Theory, highvalue companies will disclose more quality information to differentiate it from low-value companies, which are low performing companies. From a capital market perspective, a wellperforming company will reveal more information to show the company's strength in the capital market. Therefore, companies that conduct Tax Evasion will tend to disclose more information to the public in an effort to maintain its image and credibility in the presence of stakeholders.

The relationship between Tax Evasion, ICR, and firm value can also be explained by Political Cost Theory. According to this theory, large corporations will be heavily publicized and prone to government interference with their business activities because large companies are often associated with high levels of profitability and market concentration levels that lead to monopoly form. The presence of the spotlight from the public resulted in large companies very vulnerable to the occurrence of redistribution of wealth (Watts and Zimmerman, 1978). From a political point of view, some community groups have the ability to lobby in the expropriation, nationalizing, splitting of a company or affecting an industry-related regulation. Therefore, according to political cost theory, large companies are more sensitive than small firms associated with political costs. Political cost arises from the conflict of interest between the company (manager) and the government as an extension of the people who have the 
authority to transfer the wealth from the company to the community (Watts and Zimmerman, 1978). A voluntary disclosure will enhance the company's image which will further increase public acceptance and avoid confrontation between the company and the public (Milne, 2002). Voluntary disclosure by corporations shows that companies act responsibly and there is no further legal need to force them to disclose any information.

ICR can be a tool for companies to disclose more information to stakeholders. The purpose of internet use in corporate information reporting activities is to provide comprehensive and timely information to individual investors previously available only to certain parties, such as institutional investors and analysts (Ettredge et al., 2001). The use of ICR is also one of the company's efforts in meeting the demands of stakeholders to provide information that can be accessed by all interested parties. So far, company information is reproduced and disseminated in hard copy. Company information presented in printed form makes it difficult for stakeholders to get it. Therefore, stakeholders need a flexible reporting system in which they can get information in an easier way. Meanwhile, according to Gandia (2008) there are five benefits of ICR: ICR facilitates communications between companies and investors by providing all kinds of company related information, reducing distribution costs and improving the timeliness of corporate information, encouraging shareholder involvement in the life of a company due to internet technology enables companies to communicate online with shareholders and remove geographic barriers that may prevent shareholder participation, help companies to distribute information equally to all stakeholders useful for stock price formation and efficiency of stock market operations, and enhance the credibility of corporate good corporate governance practices so that will improve the company's image in the presence of stakeholders. Based on this, the third hypothesis in this study are:

$\mathrm{H}_{3}$ : Tax Evasion affects the firm value through the level of Internet Corporate Reporting disclosure.

\section{METHODS OF RESEARCH}

The population that became the object in this study covers all manufacturing companies listed on the Indonesia Stock Exchange (IDX) in the period 2016. Selection of manufacturing companies as a research population due to manufacturing companies is the largest contributor to tax revenue in Indonesia compared to other sectors until the third quarter 2017 reached $\mathrm{Rp} 224.95$ trillion or about $31 \%$ of state revenue (https://www.merdeka.com, 2017). The number grew $16.63 \%$ over the same period last year. However, the manufacturing company as a taxpayer is often the subject of the Directorate General of Taxes examination because in 2012 there were 4000 foreign investment companies that reported but did not have the amount of tax due to losses for 7 consecutive years (Prakosa, 2014). Determination of the sample using purposive sampling method with criteria: 1) The company has a website used to report financial and/or nonfinancial information, 2) the company's website is not only as a promotional tool, 3) The company's website is not under costrustruction, 4) the company has complete data related to the variables used in the study. The number of samples used in this study is 121 manufacturing companies. Exogenous variable in this research is Tax Evasion (TEV), that is effort done by a taxpayer to alleviate tax burden by violating a law (Mardiasmo, 2009). Tax Evasion is proxied by GAAP ETR, which is an effective tax rate based on applicable financial accounting reporting standards. The low ETR GAAP shows the income tax expense is less than the income before tax. Endogen variable in this research is the firm value (FIRMVALUE), that is a perception of an investor to a success rate of a company which often associated with share price (Pohan, 2008). Firm value is measured by Tobin s Q Index. The intervening variable in this study is the level of disclosure of ICR, ie the level of completeness of information disclosed by the company through the company website (Homayoun and Rahman, 2009). The level of ICR disclosure in this study was measured using an unregulated index of ICR disclosure by adopting 71 ICR components developed by Marston and Polei (2004) covering the type of information (CONTENT) and presentation media 
(PRESENTATION) used by companies to disclose information online. Disclosure index calculation is done by comparing the conformity between the content of information presented on the company website with disclosure items. If the item is disclosed by the company, it is given a score of 1 and if not disclosed a score of 0 . Analysis of data used is Structural Model with Observed Variables, ie Path Analysis. Path Analysis is tied to a number of assumptions for parameter estimates to have best linear unbiased estimator properties. Assumptions that must be met in order to obtain unbiased estimates, including multicollinearity test, heterokedasticity test, and normality test. This research uses crosssectional data so that autocorrelation test is not performed because autocorrelation problem is often found in time series data (Ghozali, 2009: 100). Hypothesis testing in this research is formulated in the form of equation as follows:

$$
\begin{gathered}
\text { DSCORE ICR } \\
\text { Iit, }=\alpha+P_{2} T_{E V} V_{i, t}+e_{1} \\
\text { FIRM VALUE } i, t=\alpha+P_{1} \operatorname{TEV}_{i, t}+P_{3} \operatorname{DSCORE}_{i, t}+e_{2}
\end{gathered}
$$

\section{RESULTS OF STUDY}

Analysis of Area of ICR Disclosure. Table 4.1 illustrates the level of ICR disclosure of 121 manufacturing companies being sampled. Based on Table 4.1 it is known that the quality of information disclosure from 121 sample companies varies greatly. Level of disclosure CONTENT has a minimum value of 20.00 and its maximum value of 97.78 . Level of disclosure PRESENTATION has a minimum value of 15.38 and its maximum value is 96.15 . Meanwhile, the maximum value and minimum value of total disclosure level (DSCORE) are 95.77 and 19.72. This shows that there is a very high variation on the level of information disclosure through the website by manufacturing companies in Indonesia which is indicated by the range of DSCORE, CONTENT, and PRESENTATION ie 76.05, 77.78, and 80.77. Range to PRESENTATION highest, this indicates that there are companies that take advantage of the presentation of the media via the Internet maximally and there are companies that are limited to having a website without exploring the benefits of components in the website that can facilitate stakeholders in finding information. The majority of manufacturing companies only make disclosure of 21.13. Although DSCORE has a high maximum value, the average value of DCSORE reaches only 51.2979. Based on Table 4.1 it is also known that the average value of the disclosure of CONTENT and PRESENTATION also reached only 53.7737 and 47.0119. These conditions indicate that the level of information disclosure online in Indonesia is still relatively low, both from the content of information and how to deliver it. The results also show that manufacturing companies in Indonesia still prioritize the quality of corporate information presented online and have not maximized the advantages of media presentations held by internet technology to disclose information to the public.

Table 1 - The Results of Descriptive Statistic Analysis of Level of ICR Disclosure

\begin{tabular}{|c|c|c|c|c|}
\hline \multicolumn{2}{|c|}{$\mathrm{n} / \mathrm{n}$} & DSCORE & CONTENT & PRESENTATION \\
\hline \multirow{2}{*}{$\mathrm{N}$} & Valid & 121 & 121 & 121 \\
\cline { 2 - 5 } & Missing & 0 & 0 & 0 \\
\hline \multicolumn{2}{|c|}{ Mean } & 51,2979 & 53,7737 & 47,0119 \\
\hline Median & 47,8900 & 48,8900 & 42,3100 \\
\hline Mode & 21,13 & 48,89 & 23,08 \\
\hline Std. Deviation & 22,02292 & 23,65337 & 80,77 \\
\hline Range & 76,05 & 77,78 & 15,38 \\
\hline Minimum & 19,72 & 20,00 & 96,15 \\
\hline
\end{tabular}

Descriptive Statistics Analysis. A descriptive statistic is a statistic that serves to collect, process, present, and analyze quantitative data descriptively. Specifically, descriptive statistics are used to indicate the amount of data and show the maximum value, minimum 
value, mean value, and standard deviation value of each variable used in the study. The number of samples $(\mathrm{N})$ in this study were 121 manufacturing companies listed on the IDX in the period 2016. This study used three types of variables, namely the exogenous, endogenous, and intervening variables. Exogenous variable in this research is Tax Evasion (TEV). Based on Table 4.2, TEV has a minimum value of 0.00 and a maximum value of 2.20 with an average value of 0.2958 and a standard deviation of 0.32039 . The standard deviation value greater than the mean value shows the large data distribution between the lowest TEV values and the highest TEV values. The majority of manufacturing companies have a GAAP ETR value of 0.25 . The endogenous variable of this study is a firm value (FIRMVALUE). The minimum and maximum values of the FIRMVALUE variable are 0.08 and 2.08 with an average value of 1.0455 and a standard deviation of 0.69919 . The standard deviation value that is smaller than the average value indicates that the FIRMVALUE variable has a relatively small difference between each firm. The majority of manufacturing companies have a firm value of 0.50 . Meanwhile, the intervening variable in this study is the area of ICR disclosure (DSCORE). DSCORE has a minimum value of 19.72 and a maximum value of 95.77 with an average value of 51.2979 and a standard deviation value of 22.02292. The standard deviation value that is smaller than the average value indicates that the DSCORE variable has a relatively small difference between each company. The majority of manufacturing companies have DSCORE value of 0.25 .

Table 2 - The Result of Descriptive Statistic Analysis of Research Variables

\begin{tabular}{|c|c|c|c|c|}
\hline \multicolumn{2}{|c|}{$\mathrm{n} / \mathrm{n}$} & TEV & DSCORE & FIRMVALUE \\
\hline \multirow{2}{*}{$\mathrm{N}$} & Valid & 121 & 121 & 121 \\
\cline { 2 - 5 } & Missing & 0 & 0 & 0 \\
\hline \multicolumn{2}{|c|}{ Mean } &, 2958 & 51,2979 &, 0455 \\
\hline Median &, 2500 & 47,8900 &, 5000 \\
\hline Mode &, 25 & 21,13 &, 69919 \\
\hline &, 32039 & 22,02292 & 2,90 \\
\hline Std. Deviation & 2,20 & 76,05 &, 08 \\
\hline Range &, 00 & 19,72 & 2,98 \\
\hline
\end{tabular}

Classical Assumption Analysis. The multicollonierity test aims to test whether in the regression model found the existence of a correlation between independent variables. Multicollinearity in this study was detected using Tolerance and Variance Inflation Factor (VIF) values. Common cutoff values used to indicate the presence of multicollinearity is Tolerance values $\leq 0.10$ or VIF values $\geq 10$. Based on Table 4.3 it is known that no independent variable has a Tolerance value less than 0.1 and no single independent variable has a VIF value more than 10. This means there is no correlation between independent variables. Thus, it can be concluded that there is no multicollinearity among independent variables in this research model.

Table 3 - Multicollonearity Test Results

Coefficients $^{a}$

\begin{tabular}{|c|c|c|c|c|c|c|c|}
\hline \multirow{2}{*}{ Model } & \multicolumn{2}{|c|}{ Unstandardized Coefficients } & Standardized Coefficients & \multirow{2}{*}{$\mathrm{t}$} & \multirow{2}{*}{ Sig. } & \multicolumn{2}{|c|}{ Collinearity Statistics } \\
\cline { 2 - 4 } \cline { 6 - 8 } & $\mathrm{B}$ & Std. Error & Beta & & Tolerance & VIF \\
\hline (Constant) &, 798 &, 178 & & 4,473 &, 000 & & \\
1 TEV &,- 334 &, 196 &,- 153 & $-1,704$ &, 091 &, 964 & 1,038 \\
DSCORE &, 007 &, 003 &, 213 & 2,368 &, 020 &, 964 & 1,038 \\
\hline
\end{tabular}

a. Dependent Variable: FIRMVALUE

The heteroskedasticity test aims to test whether in the regression model there is a variance inequality of the residual one observation to another observation. This study uses Glejser test to detect the presence or absence of heterokedastisitas. Based on Table 4.4 it is known that none of the independent variables that are a statistically significant influence on 
the dependent variable, the absolute residual value (AbsUt). This is evident from the probability significance of all independent variables that are above the $5 \%$ confidence level. Thus, it can be concluded that the regression model is free from the problem of heteroskedasticity.

Table 4 - Heteroscedasticity Test Results

Coefficients $^{a}$

\begin{tabular}{|c|c|c|c|c|c|c|}
\hline \multirow{2}{*}{\multicolumn{2}{|c|}{ Model }} & \multicolumn{2}{|c|}{ Unstandardized Coefficients } & \multirow{2}{*}{$\frac{\text { Standardized Coefficients }}{\text { Beta }}$} & \multirow[b]{2}{*}{ t } & \multirow{2}{*}{ Sig. } \\
\hline & & $B$ & Std. Error & & & \\
\hline & (Constant) & ,434 & 100 & & 4,325 &, 000 \\
\hline 1 & TEV &,- 062 & ,110 &,- 052 &,- 562 &, 575 \\
\hline & DSCORE &, 003 & ,002 & 149 & 1,610 & ,110 \\
\hline
\end{tabular}

a. Dependent Variable: AbsUt

The normality test aims to test whether in the regression model, the residual or residual variable has a normal distribution. This study uses Kolmogorov-Smirnov test with $5 \%$ significance level to detect presence or absence of normality. Data is said to be normal if the value of significance ( $p$-value) for each variable analyzed is greater than 0.05 . The result of normality test in Table 4.5 shows that Kolmogrov-Smirnov value is 0.155 and significant at 0.05 because $p$-value is $0.00(<0.05)$. Due to the significance value less than 0.05 , it can be concluded that the nuisance variable or residual value of the research model is not normally distributed.

Table 5 - Normality Test Results

One-Sample Kolmogorov-Smirnov Test

\begin{tabular}{|c|c|c|}
\hline \multicolumn{2}{|c|}{$\mathrm{n} / \mathrm{n}$} & Unstandardized Residual \\
\hline $\begin{array}{l}\text { Normal Parameters }{ }^{\mathrm{a}, \mathrm{b}} \\
\text { Most Extreme Differences } \\
\text { Test Statistic } \\
\text { Asymp. Sig. (2-tailed) }\end{array}$ & $\begin{array}{l}\text { Mean } \\
\text { Std. Deviation } \\
\text { Absolute } \\
\text { Positive } \\
\text { Negative }\end{array}$ & $\begin{array}{c}121 \\
, 0000000 \\
, 67019827 \\
, 155 \\
, 155 \\
-, 086 \\
, 155 \\
, 000^{\mathrm{C}} \\
\end{array}$ \\
\hline
\end{tabular}

a. Test distribution is Normal.

b. Calculated from data.

c. Lilliefors Significance Correction.

Table 6 - Normality Test Results after Transformation

One-Sample Kolmogorov-Smirnov Test

\begin{tabular}{|c|c|c|}
\hline \multicolumn{2}{|c|}{$\mathrm{n} / \mathrm{n}$} & Unstandardized Residual \\
\hline $\begin{array}{l}\text { Normal Parameters } \\
\text { Most Extreme Differences } \\
\\
\text { Test Statistic } \\
\text { Asymp. Sig. (2-tailed) }\end{array}$ & $\begin{array}{l}\text { Mean } \\
\text { Std. Deviation } \\
\text { Absolute } \\
\text { Positive } \\
\text { Negative }\end{array}$ & $\begin{array}{c}121 \\
, 0000000 \\
, 68949955 \\
, 076 \\
, 054 \\
-, 076 \\
, 076 \\
, 083^{\mathrm{C}}\end{array}$ \\
\hline
\end{tabular}
a. Test distribution is Normal.
b. Calculated from data.
c. Lilliefors Significance Correction.

To overcome the problem of normality, transformed data into the form of natural logarithm with a semilog regression model. Based on Table 4.6 it is known that the normality test using the semilog regression model where only the dependent variable data, ie the 
variable of firm value (FIRMVALUE) transformed into the form of natural logarithm able to make the research model free from the problem of normality. This is indicated by the Kolmogrov-Smirnov value of 0.076 and not significant at 0.05 because $p$-value has a value greater than 0.05 , which is 0.083 .

Hypothesis Testing Results. The first time, the calculation of path coefficients to determine whether the hypothesis in this study accepted or rejected. The calculation of path coefficient in this research is as follows:

Coefficient of Line Model I:

Referring to the output of Regression Model 1 shown in Table 4.7, it can be seen that the significance value of the TEV variable is less than 0.05 , ie 0.036 . This result gives the conclusion that Regression Model I, ie Tax Evasion variable (TEV) has significant effect on ICR (DSCORE) disclosure level. The unstandardized beta coefficient value of TEV in Table 5.7 is -13.101 . This number represents the path or path value of $P 2$. The value of $R$ Square $\left(R^{2}\right)$ shown in Table 4.8 is 0.036 . This indicates that the contribution or contribution of TEV influence to DSCORE is $3.60 \%$ while the remaining $96.40 \%$ is the contribution of other variables not included in this research. Meanwhile, for value $e_{1}$ can be searched with the formula $e_{1}=\sqrt{ }(1-0,036)=0,98184$.

Table 7 - Coefficient Test Result of Model Path 1

Coefficients $^{a}$

\begin{tabular}{|c|c|c|c|c|c|}
\hline \multirow{2}{*}{ Model } & \multicolumn{2}{|c|}{ Unstandardized Coefficients } & Standardized Coefficients & \multirow[b]{2}{*}{$t$} & \multirow{2}{*}{ Sig. } \\
\hline & $\mathrm{B}$ & Std. Error & Beta & & \\
\hline $\begin{array}{cc} & \text { (Constant) } \\
\text { TEV }\end{array}$ & $\begin{array}{l}55,173 \\
-13,101\end{array}$ & $\begin{array}{l}2,691 \\
6,186\end{array}$ & -191 & $\begin{array}{l}20,501 \\
-2,118\end{array}$ & $\begin{array}{l}.000 \\
.036\end{array}$ \\
\hline
\end{tabular}

a. Dependent Variable: DSCORE

Table 8 - Test Results Influence Model 1

Model Summary

\begin{tabular}{|c|c|c|c|c|}
\hline Model & $\mathrm{R}$ & $\mathrm{R}$ Square & Adjusted R Square & Std. Error of the Estimate \\
\hline 1 &, $191^{\mathrm{a}}$ &, 036 &, 028 & 21,70988 \\
\hline
\end{tabular}

a. Predictors: (Constant), TEV

Coefficient of Line Model 2:

Referring to the output of Regression Model 2 shown in Table 4.9, it can be seen that the significance value of the TEV and DSCORE variables is less than 0.05 , ie 0.017 and 0.031. This result gives the conclusion that Regression Model 2, ie Tax Evasion (TEV) variable and ICR (DSCORE) disclosure area have significant effect to firm value (FIRMVALUE). The unstandardized coefficients of beta values of TEV and DSCORE are respectively in Table 4.9 of -0.486 and 0.006 . Unstandardized beta TEV represents path or path value P1 and unstandardized number beta DSCORE is path P3. The value of R Square (R2) contained in Table 4.10 is 0.085 . This shows that contribution or contribution of influence of TEV and DSCORE to FIRMVALUE is $8,50 \%$ while the rest $96,40 \%$ is contribution from other variables not included in this research. Meanwhile, for the value of e2 can be searched with the formula e $1=\sqrt{ }(1-0.085)=0.95656$.

Table 9 - Coefficient Test Result of Model 2]

Coefficients $^{a}$

\begin{tabular}{|c|c|c|c|c|c|}
\hline \multirow{2}{*}{ Model } & \multicolumn{2}{|c|}{ Unstandardized Coefficients } & Standardized Coefficients & \multirow{2}{*}{ Sig. } \\
\cline { 2 - 7 } & $\mathrm{B}$ & Std. Error & Beta & $-2,048$ &, 043 \\
\hline \multirow{2}{*}{1 (Constant) } &,- 376 &, 183 & & $-2,411$ &, 017 \\
TEV &,- 486 &, 202 &,- 214 & 2,190 &, 031 \\
\hline
\end{tabular}

a. Dependent Variable: LnFIRMVALUE 
Table 10 - Test Result Influence Model 2

Model Summary

\begin{tabular}{|l|l|l|l|l|}
\hline Model & R & R Square & Adjusted R Square & Std. Error of the Estimate \\
\hline 1 &, $316^{\text {a }}$ &, 100 &, 085 &, 69532 \\
\hline
\end{tabular}

a. Predictors: (Constant), DSCORE, TEV

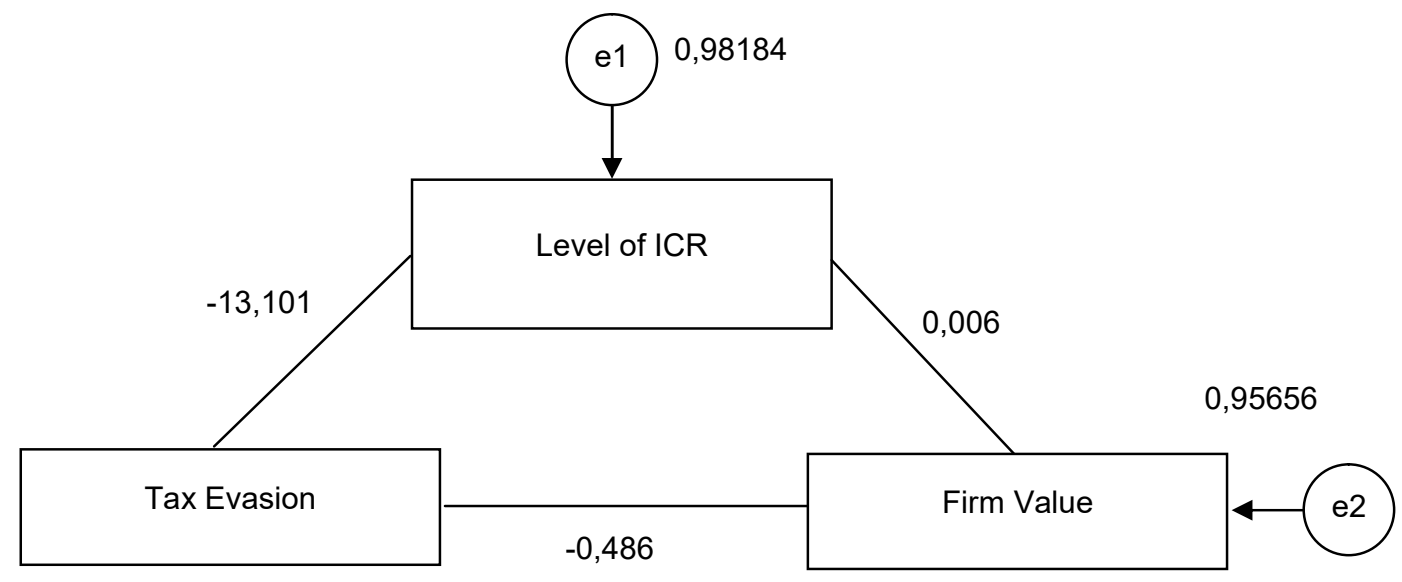

Figure 1 - Result of Path Coefficient

The path analysis results show that TEV has an immediate effect on FIRMVALUE and indirectly affects FIRMVALUE via DSCORE. In other words, the first, second, and third hypothesis in this study is accepted. The magnitude of the direct effect is -13.101 , whereas the magnitude of indirect influence is calculated by multiplying the indirect coefficient, ie P2 $x$ $\mathrm{P} 3=(-13.101) \times(0.006)=-0.07861$ or the total effect of TEV to DSCORE is P1 $+(\mathrm{P} 2 \times \mathrm{P} 3)=$ $-0.486+(-13,101 \times 0.006)=-0.564606$.

\section{DISCUSSION OF RESULTS}

Effect of Tax Evasion on the level of Internet Corporate Reporting disclosure. Based on the results of hypothesis testing, the first hypothesis $(\mathrm{H} 1)$ which state that the Tax Evasion effect on the level of disclosure of Internet Corporate Reporting is accepted. The effect of TEV on DSCORE is $3.60 \%$. This is indicated by the magnitude of R Square (R2) as shown in Table 4.8, which is 0,036 . Meanwhile, based on the unstandardized beta coefficient value of TEV in Table 4.7 of -13.101 indicates that the influence of TEV on DSCORE is negative. That is, the more often companies do Tax Evasion then the company will be more narrow type of information (content) and presentation method used by companies to disclose information through the website. The results of this study support the research of Hope et al. (2013), ie companies that do tax evasion tend to disclose fewer financial information to hide their cheats.

However, the results of this study contrasted with Agency theory, Signaling Theory, and Political cost theory. According to agency theory, ICR practice is the company's effort to reduce information asymmetry. The information presented on the company's website will reduce the uncertainty about the prospects of the company to come. However, companies will disclose less information if they take tax evasion because disclosure of too much information will be a competitive disadvantage for them. Meanwhile, based on Signaling Theory, management will have a stronger push to disseminate company information, especially financial information in order to increase investor confidence when the company performs well (Oyelere et al., 2003). A healthy corporate financial condition is a positive signal for external parties, especially for investors. Tax evasion actions by the company can be a signal that the company's financial condition is not good or in other words indicates the inability of the company in managing its finances. 
Therefore, the wider the company discloses the information, the market will catch it as a negative signal. According to Political Cost Theory, the company will disclose more information to reduce political costs, one of which is taxes and increases public support for the company's operations. Political cost arises from the conflict of interest between the company (manager) and the government as an extension of the people who have the authority to transfer the wealth from the company to the community (Watts and Zimmerman, 1978). A voluntary disclosure will enhance the company's image which will further increase public acceptance and avoid confrontation between the company and the public (Milne, 2002). Voluntary disclosure by corporations shows that companies act responsibly and there is no further legal need to force them to disclose any information. This is in contrast to the company's tax evasion. The more companies disclose the information, the government will easily find the fraudulent actions that the company did and impose sanctions in the form of fines or interest that will add to the company's political costs.

Effect of Tax Evasion on firm value. Based on the results of hypothesis testing, the second hypothesis $(\mathrm{H} 2)$ which state that the Tax Evasion effect on firm value is accepted. This is indicated by a significance number that is below 0.05 , ie 0.017 . Meanwhile, based on the unstandardized beta coefficient value of TEV in Table 4.9 of -0.486 indicates that the effect of TEV on FIRMVALUE is negative. That is, the more companies do Tax Evasion then the value of the company will be smaller which one of them is reflected in the low stock price. The results of this study support Agency theory, Signaling Theory, and Political cost theory. According to Agency theory, the manager (agent) who is appointed by the shareholder (principal) is expected to act to maximize the value of the company so that shareholder wealth can be achieved. However, the agent in running the company's operating activities often acts not for the interests of the principal, but acts to improve his own welfare, among others, one of them is by doing Tax Evasion to maximize corporate profits. Separation of ownership and control of the company also has the potential to generate information asymmetry because agents have more information about the company than the principal. This can ultimately lead to a decrease in stakeholder trust. According to Signaling Theory Tax Evasion actions detected by the market will decrease the value of the company through a decrease in nominal value, intrinsic value, liquidation value, book value, and market value (Christiawan and Tarigan, 2007). Meanwhile, according to Political cost theory the action of Tax Evasion resulted in a confrontation between the company and the public (Milne, 2002). This can lead to a potential decline in firm value.

Tax Evasion affects the value of the company through the extensive disclosure of Internet Corporate Reporting. Based on the results of hypothesis testing, the second hypothesis $(\mathrm{H} 3)$ which state that the Tax Evasion affect the value of the company in the area of Internet Corporate Reporting disclosure is accepted. The amount of indirect influence of TEV to FIRM VALUE via DSCORE is -0.564606 . Table 4.9 also shows a positive influence between DSCORE and FIRMVALUE. That is, although the choice of companies to disclose more information online can increase the value of the company, but when companies do Tax Evasion companies choose to disclose a little information to the public. According to Signaling Theory, the company will provide information widely and easily accessible to the public to provide a positive signal to the market for effective management performance and the company's ability to ensure the sustainability of the company so that investors are interested to invest their capital into the company. Therefore, the market can interpret as bad news if the company slightly disclose the information because it is a signal that the company's performance is bad. The existence of information asymmetry between the principle and the agent results in arbitrary activities of agents to perform Tax Avoidance in order to maximize profits or to improve their own welfare, among others in terms of obtaining investment, loans, or compensation contracts. This can be reduced by encouraging agents to disclose more information to the public. The broader the information disclosed to the public will be to increase stakeholder trust so as to increase the value of the company 


\section{CONCLUSION}

This study aims to examine the direct effect of Tax Evasion on firm value and indirect Tax Evasion's influence on firm value through the level of Internet Corporate Reporting. The test results showed that the three hypotheses in this study were accepted. Thus, it can be concluded that the choice of companies to disclose information more widely online can increase the value of the company, but when companies take action Tax Evasion companies choose to disclose a little information to the public. This is done to hide the illegal actions that the company is doing. Based on this it should be the government or the board of accounting standards to make policies that standardize the reporting of information through the website. In addition to the ICR standards, governments may also consider requiring companies to disclose information through the website. This is possible given the use of the Internet as a means of obtaining information is very wide. The existence of ICR standards and rules that require companies to disclose information online is expected to eliminate the Tax Evasion action by the company. This study has limitations that only look at the relationship between Tax Evasion variable, ICR, and firm value. Going forward, this research can be developed using a qualitative approach to see how far the broad role of ICR disclosure in reducing tax evasion. In addition, it can also be analyzed what information should be disclosed online in order to eliminate tax evasion.

\section{REFERENCES}

1. Almilia, L.S. 2009. Determining Factors Of Internet Financial Reporting In Indonesia. Journal of Accounting and Taxation. 1(1): 45-67.

2. Alvarez, I.G., I.M.G. Sanchez, dan L.R. Dominguez. 2008. Voluntary and compulsory information disclosed online The effect of industry concentration and other explanatory factors. Online Information Review. 32 (5): 596-622.

3. Aly, D., J. Simon, dan K. Hussainey. 2009. Determinants Of Corporate Internet Reporting: Evidence From Egypt. Managerial Auditing Journal. 25(2): 182-202.

4. Andreoni, J, Brian E., \& Jonathan F. (1998). Tax Compliance. Journal of Economic Literature, Vol.36, No.2, pp 818-860

5. Ashbaugh, H., K. Johnstone, dan T. Warfield. 1999. Corporate reporting on the Internet. Accounting Horizons. 13(3): 241-257.

6. Balakrishnan, K., Blouin, J., Guay, W., 2011. Does tax aggressiveness reduce financial reporting transparency?, Working paper

7. Barac, K. 2004. Financial Reporting On The Internet In South Africa. Meditari Accountancy Research. 12(1): 1-20.

8. Barako, D.G., Rusmin, dan G.Tower. 2008. Web Communication: An Indonesian Perspective. Journal of Business Management. 2(3): 53-58.

9. Bhuiyan, M.U, P.K. Biswas, dan S.P. Chowdhury. 2008. Corporate Internet Reporting Practice in Developing Economies: Evidence from Banglades. (on-line). (http://papers.ssrn.com/sol3/papers.cfm?abstract_id=1430004)

10. Bird, A. (1994) "Careers as repositories of knowledge: A new perspective on boundaryless careers", Journal of Organizational Behavior, 15(4): 325-344

11. Carpenter, C.G. and R.H. Strawser. 1970. Job selection preferences of accounting students. Journal of Accountancy (June): 84-86.

12. Christiawan, Y.J. dan J. Tarigan. 2007. Kepemilikan Manajeral: Kebijakan Hutang, Kinerja dan Nilai Perusahaan. Jurnal Akuntansi dan Keuangan. 9(1): 1-8.

13. Craven, B.M dan C.L. Marston. 1999. Financial reporting on the Internet by leading UK companies. The European Accounting Review. 8(2): 321-333.

14. Dutta, P. dan S. Bose. 2007. Web-based Corporate Reporting in Bangladesh: An Exploratory Study. The Cost and Management. 35(6): 29-45.

15. Fama, E. F. 1978. The Effect of a Firm s Investment and Financing Decision on the Welfare of its Security Holders. American Economic Review. 68: 272-28. 
16. FASB. 2000. Electronic Distribution of Business Reporting Information, Business Reporting Research Project. (on-line). (http://accounting.rutgers.edu/raw/fasb/brrp1.pdf).

17. FASB. 2001. Improving Business Reporting: Insights into Enhancing Voluntary Disclosures. (on-line). (http://www.fasb.org/brrp/brrp2.pdf).

18. Ettredge, M., V.J. Richardson., dan S. Scholz. 2001. The Presentation of Financial Information at Corporate Websites. International Journal of Accounting Information Systems. 1(2): 149-168.

19. Gandia, J.L. 2008. Determinants Of Internet-Based Corporate Governance Disclosure By Spanish Listed Companies. Online Information Review. 32(6): 791-817.

20. Ghozali, I. 2009. Aplikasi Analisis Multivariate dengan Program SPSS. Semarang: Badan penerbit Universitas Diponegoro.

21. Homayoun, S. dan R.A. Rahman. 2009. Determinants of Web-Based Corporate Reporting Among Top Public Listed Companies in Malaysia. International Journal of Arts and Sciences. 3(13): 187-212.

22. Hope, O.K., Mark (Shuai) Ma, \& Wayne B. T. (2013). Tax Avoidance And Geographic Earnings Disclosure. Journal of Accounting and Economics, 56(170-189)

23. Hunter, S. dan L.M. Smith. 2007. Impact Of Internet Financial Reporting On Emerging Markets. (on-line). (http://papers.ssrn.com/sol3/papers.cfm?abstract_id=1017078)

24. Husnan, S. 2000. Manajemen Keuangan Teori dan Penerapan (Keputusan Jangka Panjang). Yogyakarta: BPFE.

25. James, S., \& Alley, C. (2002). Tax compliance, self-assessment system and tax administration. Journal of Finance, and Management in Public Services, 2(2), 2742.

26. Jensen, S.C. dan W. Meckling. 1976. Theory of the Firm: Managerial Behavior, Agency Costs and Ownership Structure. Journal of Financial Economics. 3(4): 305-360.

27. Khan, T. 2007. Internet Financial Reporting: Disclosure about Companies on Websites. Journal of Business Systems: Governance and Ethics. 2(2): 37-46.

28. Khlifi, F. dan A. Bouri. 2009. Corporate Disclosure and Firm Characteristics: A Puzzling Relationship. Journal of Accounting: Business and Management. 17(1): 62-89.

29. Lai, S.C., C. Lin, H.C. Li, dan F.H. Wu. 2009. An Empirical Study of The Impact of Internet Financial Reporting on Stock Prices. The International Journal of Digital Accounting Research. 10(1): 1-26.

30. Lakhal, F. dan S. Boubaker. 2005. The Determinants of Web-Based Corporate Reporting in France. (on-line). (http://www.anciens105isgsousse.org/actes/samedi/28-032009_9H00-10H30/Session2/Lakhal-Boubaker.pdf).

31. Lymer, A., R. Debreceny, G. Gray, dan A. Rahman. 1999. Business Reporting on the Internet. London: International Accounting Standards Committee.

32. Marston, C. dan A. Polei. 2004. Corporate reporting on the Internet by German companies. International Journal of Accounting Information Systems. 5(1): 285-311.

33. Merdeka.com (2017) Penyumbang pajak signifikan, pemerintah fokus beri nilai tambah industri manufaktur, https://www.merdeka.com/uang/penyumbang-pajak-signifikanpemerintah-fokus-beri-nilai-tambah-industri-manufaktur.html

34. Milne, M.J. 2002. Positive Accounting Theory, Political Costs And Social Disclosure Analyses: A Critical Look. Critical Perspectives on Accounting. 13(3): 369-395.

35. Mulianti, F. M. 2010. Analisis Faktor-Faktor Yang Mempengaruhi Kebijakan Hutang Dan Pengaruhnya Terhadap Nilai Perusahaan. Unpublished Thesis, Universitas Diponegoro, Semarang.

36. Oyelere, P., F. Laswad, dan R. Fisher. 2003. Determinants of Internet Financial Reporting by New Zealand Companies. Journal of International Financial Management and Accounting. 14(1): 26-63.

37. Prakosa, Kesit Bambang. 2014. Pengaruh Profitabilitas, Kepemilikan Keluarga, dan Corporate Governance terhadap Penghindaran Pajak di Indonesia. Jurnal. http://multiparadigma.lecture.ub.ac.id/files/2014/09/100.pdf.

38. Refleksi Tingkat Kepatuhan Wajib Pajak, Rabu, 23 Maret 2016, http://www.pajak.go.id/content/article/refleksi-tingkat-kepatuhan-wajib-pajak' 
39. Roth, J. A., Scholtz, J. T., \& Witte, A. D. (1989). Taxpayer compliance: An agenda for research. Philadelphia: University of Pennsylvania Press.

40. Santoso, I., \& Ning R. (2013). Corporate Tax Management. Jakarta: Ortax

41. Scholes, Myron, Mark Wolfson, Merle Erickson, Edward Maydew, and Terry Shevlin, 2009. Taxes and Business Strategy: A Planning Approach, 4 Ed., Prentice-Hall Inc., Upper Saddle River, NJ.

42. Singhvi, S.S. dan H.B. Desai. 1971. An Empirical Analysis of The Quality of Corporate Financial Disclosure. The Accounting Review. 46 (1): 129-138.

43. Wahidahwati. 2002. Pengaruh Kepemilikan Manajerial dan Kepemilikan Institusional pada Kebijakan Hutang Perusahaan: Sebuah Perspektif Theory Agency. Jurnal Riset Akuntansi Indonesia. 5 (1): 1-16.

44. Warskett, G., S. Winer, and W. Hettich (1998): "The Complexity of Tax Structure in Competitive Political Systems," International Tax and Public Finance, 5, 123- 151.

45. Watts, R. dan J. Zimmerman. 1978. Towards A Positive Theory Of The Determination Of Accounting Standards. The Accounting Review. 53: 112-134.

46. Wilis, M. 2004. XBRL: Leveraging the Internet for Corporate Reporting. (on-line), (http://www.pwc.com/rebusinessXBRL) 